OxiDATIVE damage is involved in the pathogenic process of idiopathic chronic inflammatory bowel disease. Although specific intervention in the oxidative cascade showed promising results in animal models and preliminary patient trials, the clinical efficacy of antioxidants still has to be established. Mucosa protection, for example by dietary fatty acids, seems to attenuate the in testinal inflammatory process as well but awaits definite clinical proof for the treatment of inflam matory bowel disease

Key words: antioxidants, butyrate, Crohn's disease, fatty acids, fish oil, inflammatory bowel disease, reactive oxygen metabolites, superoxide dismutase, ulcerative colitis

\section{Antioxidants and mucosa protectives: realistic therapeutic options in inflammatory bowel disease?}

\author{
L. Kruidenier and H. W. Verspaget ${ }^{\mathrm{CA}}$
}

Department of Gastroenterology and Hepatology, Leiden University Medical Center, Building 1 C4-P, PO Box 9600, 2300 RC Leiden, The Netherlands

\author{
${ }^{\mathrm{CA}}$ Corresponding Author \\ Tel: $(+31) 715262680$ \\ Fax: $(+31) 715248115$ \\ Email: \\ h.w.verspaget@gastroenterology.medfac.leidenuniv.nl
}

\section{Introduction}

The aetiology of Crohn's disease (CD) and ulcerative colitis (UC), the two forms of inflammatory bowel disease (IBD), remains as yet unknown, which hampers the development of innovative, custom-made IBD therapies. Existing therapies are often aimed at general mediators or mechanisms of inflammation. Over the past decades, however, knowledge of particular molecular, biochemical and inflammatory events in IBD has increased considerably. New concepts explaining how these events relate to intestinal tissue damage have led to new potentially effective treatment strategies for IBD aimed at counte racting oxidative stress or providing mucosa protection. Some of these therapies were found to have clinical success while others have already been abandoned again, as will be discussed in this short selective review.

\section{Antioxidants}

A growing body of evidence indicates excessive production of reactive oxygen metabolites (ROMs) as a direct or indirect cause of mucosal tissue damage in IBD (reviewed in Yamada and Grisham ${ }^{1}$ ). The principal source of ROMs in IBD are the phagocytic leukocytes. During episodes of inflammation these cells massively infiltrate the intestinal mucosa, where on activation they synthesize and release large amounts of ROMs. Another major ROM producer is the epithelial and endothelial cell-derived enzyme xanthine oxidase. This enzyme is formed and activated after periods of ischaemia and reperfusion, a process implicated in the vasculitis-associated microinfarctions at the intestinal level which are thought to contribute to the pathogenesis of IBD, particularly in CD.

The chronic nature of IBD implies an enduring tissue exposure to ROMs. Although the intestinal mucosa contains a wide variety of endogenous antioxidant defence mechanisms, their levels are relatively low compared with those in other organs (e.g. liver, lung). Moreover, the efficacy of these systems may be impaired during inflammation, partly as a result of autooxidation. Thus, IBD mucosa may be in a constant state of oxidative stress, posing a serious threat to intestinal tissue homeostasis.

Interestingly, attenuating oxidative stress has fortuitously already been a therapeutic strategy for almost 50 years. Commonly used drugs in the treatment of IBD, in particular sulphasalazine and its active moiety 5-aminosalicylic acid (5-ASA), were found to be potent ROM scavengers. However, this mechanism is just one of the many pharmacological actions of these agents. It may be clinically relevant to develop therapies specifically aimed at re-balancing the oxidative homeostasis in IBD. 


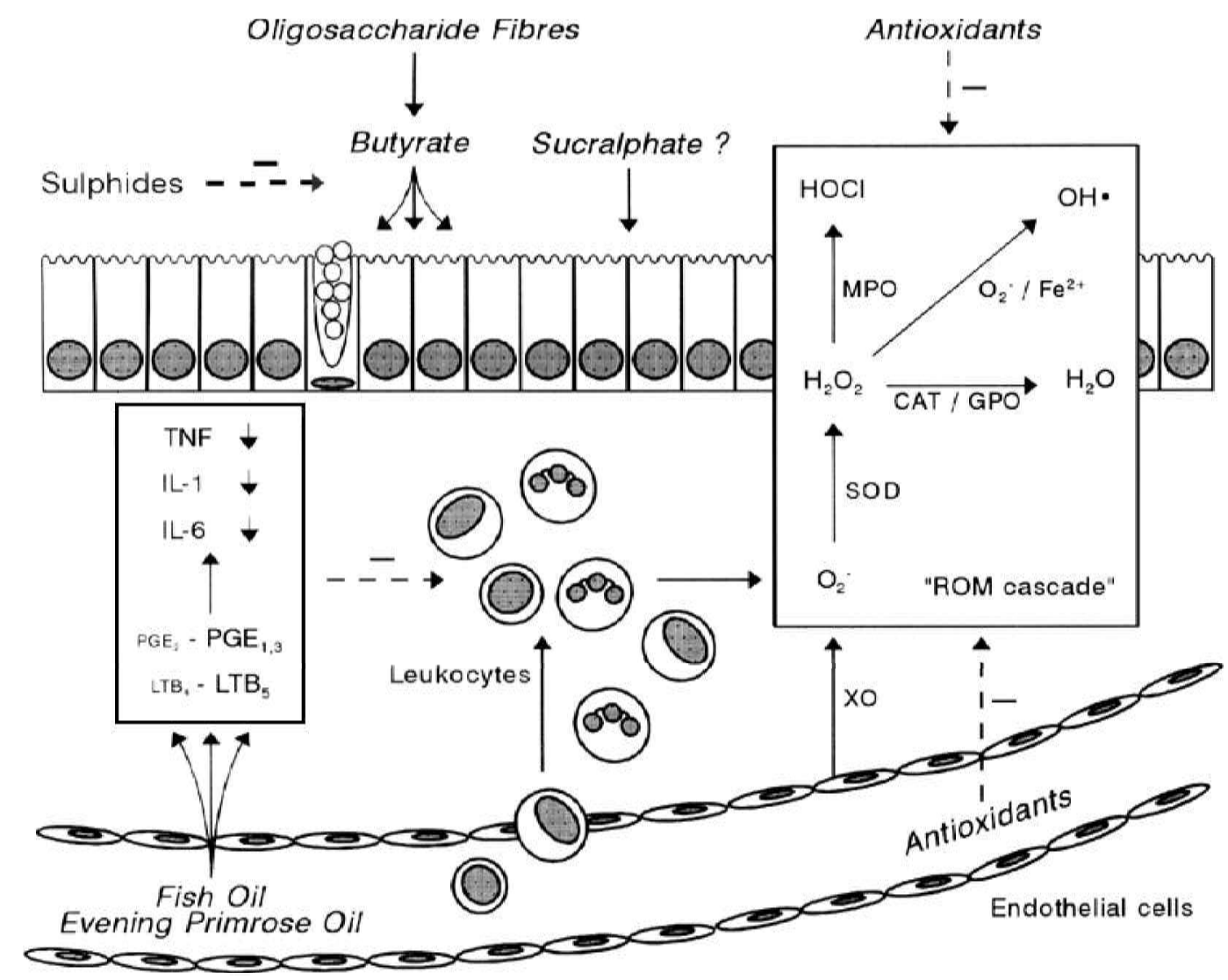

FIG. 1. Simplified schematic representation of mucosa protective and antioxidant treatment strategies in IBD. For detailed explanation, see text. CAT, catalase; GPO, glutathione peroxidase; MPO, myeloperoxidase; SOD, superoxide dismutase; XO, xanthine oxidase.

\section{ROM chemistry}

The cascade of ROM production (see Fig. 1) is initiated with the formation of the superoxide anion $\left(\mathrm{O}_{2}^{-}\right)$by a one-electron reduction of oxygen. $\mathrm{O}_{2}^{-}$ itself is a relatively unharmful oxidant, but it is dismutated spontaneously or enzymatically by superoxide dismutase (SOD) to yield the more reactive metabolite hydrogen peroxide $\left(\mathrm{H}_{2} \mathrm{O}_{2}\right)$. The easily diffusable and rather long-lived $\mathrm{H}_{2} \mathrm{O}_{2}$ is intracellularly detoxified to water by the enzymes catalase or glutathione peroxidase. However, $\mathrm{H}_{2} \mathrm{O}_{2}$ can also be metabolized to the secondary ROMs hydroxyl radical $(\mathrm{OH} \bullet)$ and hypochlorous acid $(\mathrm{HOCl}) . \mathrm{OH} \bullet$, formed by the combination of $\mathrm{O}_{2}^{-}$and $\mathrm{H}_{2} \mathrm{O}_{2}$ in a metal catalysed reaction, is extremely reactive with virtually every molecule it encounters. $\mathrm{HOCl}$ is formed via the action of myeloperoxidase (MPO) from activated phagocytes and is a powerful ROM, with strong oxidizing and chlorinating capabilities. Hypochlorous acid is also known to inactivate protease inhibitors (e.g. $\alpha_{1}$-antitrypsin), which disturbs the proteinase-antiproteinase balance and leads to propagation of extracellular matrix degradation and mucosal tissue damage.

\section{Strategies of antioxidant therapy}

In the past decade, a slowly increasing amount of literature emerged on the evaluation of drug-induced intervention strategies, specifically aimed at prevention or attenuation of intestinal oxidative stress (see Table 1 and Fig. 1). Basically, these approaches include inhibition of ROM producing enzymes, direct scavenging of ROMs, or improvement of cellular antioxidant pools. Most investigations, however, used animal models of colitis, whereas specific antioxidant trials in IBD patient groups are rare.

The principal ROMs involved in tissue damage in IBD or induced colitis in animals have not been defined. Theoretically, the most promising therapeutic antioxidant compounds would be those agents which would decimate the $\mathrm{O}_{2}^{-}$production, thus aborting the ROM cascade. Production of $\mathrm{O}_{2}^{-}$can be decreased by administration of allopurinol, an efficient inhibitor of xanthine oxidase. In UC patients, allopurinol has been reported to intensify the efficacy of sulphasalazine/prednisolone regimens, ${ }^{2}$ and to prevent or terminate pouchitis. ${ }^{3}$ Furthermore, in rats the severity of colonic inflammation induced by acetic acid or mitomycin $\mathrm{C}$ was moderately reduced 
Table 1. Strategies of antioxidant therapy in animal colitis models and IBD patients

\begin{tabular}{|c|c|c|c|c|}
\hline Mechanism & Compound & Patients/model & Response & Ref. \\
\hline \multirow[t]{6}{*}{$\mathrm{O}_{\overline{2}}$ scavenger } & SOD & 26 CD patients & $\begin{array}{l}\text { s.c./i.m. bovine CuZnSOD resulted in } 64 \% \text { short term, } \\
\text { and } 82 \% \text { long term positive results }\end{array}$ & 8 \\
\hline & SOD & $\begin{array}{l}4 \mathrm{CD}, 4 \cup \mathrm{UC} \\
\text { patients }\end{array}$ & i.m. bovine CuZnSOD resulted in $87 \%$ remission rates & 9 \\
\hline & SOD & $\begin{array}{l}\text { Acetic acid, rat, } \\
\text { guinea pig }\end{array}$ & $\begin{array}{l}\text { R-hu-CuZnSOD enemas reduced colonic necrosis and } \\
\text { inflammatory cell infiltrate, associated with lower } \mathrm{LTB}_{4} \\
\text { levels. MnSOD was inactive at similar doses }\end{array}$ & 6 \\
\hline & SOD & TNBS, rabbit & $\begin{array}{l}\text { i.v. hu-SOD prevented colitis and lowered levels of } \\
\text { LTB }_{4} \text { and } \text { PGE }_{2}\end{array}$ & 7 \\
\hline & PEG-SOD & Acetic acid, rat & $\begin{array}{l}\text { i.v. doses decreased inflammation. } 75 \% \text { of the animals } \\
\text { did not respond }\end{array}$ & 4 \\
\hline & lecithin-SOD & DSS, rat & $\begin{array}{l}\text { i.v. doses suppressed progression of bloody stools, } \\
\text { formation of erosions, and inflammatory cell infiltrate }\end{array}$ & 10 \\
\hline $\begin{array}{l}\text { SOD mimetic, } \\
\text { catalase mimetic }\end{array}$ & $\begin{array}{l}\mathrm{Cu}(I I)_{2}(3,5- \\
\mathrm{DIPS})_{4}\end{array}$ & Acetic acid, rat & $\begin{array}{l}\text { Oral administration decreased inflammatory scores, } \\
\text { associated with less diarrhoea }\end{array}$ & 11 \\
\hline SOD mimetic & $\begin{array}{l}\text { TEMPOL } \\
\text { (nitroxide) }\end{array}$ & $\begin{array}{l}\text { TNBS, rat } \\
\text { Acetic acid, rat }\end{array}$ & $\begin{array}{l}\text { i.g. dose decreased mucosal lesion area and } \\
\text { inflammatory cell infiltrate }\end{array}$ & 12 \\
\hline SOD mimetic & $\begin{array}{l}\text { U74006F } \\
\text { (lazaroid) }\end{array}$ & TNBS, rat & $\begin{array}{l}\text { i.g. dose decreased inflammation, edema, and ROM } \\
\text { production }\end{array}$ & 13 \\
\hline $\begin{array}{l}\text { SOD mimetic, } \\
\text { sparing of } \\
\text { glutathione }\end{array}$ & Rebamipide & TNBS, rat & $\begin{array}{l}\text { i.p. doses prevented antioxidant enzyme impairment } \\
\text { and reduced severity of colitis }\end{array}$ & 14 \\
\hline \multirow[t]{2}{*}{$\mathrm{OH} \bullet$ scavenger } & DMSO & 85 UC patients & $\begin{array}{l}\text { Oral administration increased remission rates (within } \\
2 \text { weeks). Prophyla ctic treatment decreased relapse } \\
\text { rates (within } 12 \text { months) }\end{array}$ & 2 \\
\hline & DMSO & Acetic acid, rat & Oral administration failed to improve inflammation & 4 \\
\hline $\mathrm{OH} \bullet$ scavenger & Deferoxamine & Acetic acid, rat & i.m. doses failed to improve inflammation & 4 \\
\hline $\mathrm{H}_{2} \mathrm{O}_{2}$ scavenger & Catalase & $\begin{array}{l}\text { Acetic acid, rat } \\
\text { Mitomycin } \mathrm{C} \\
\text { rat }\end{array}$ & $\begin{array}{l}\text { i.p. doses decreased inflammation, associated with } \\
\text { less diarrhoea }\end{array}$ & 5,11 \\
\hline \multirow[t]{3}{*}{$\begin{array}{l}\text { Xanthine } \\
\text { oxidase inhibitor }\end{array}$} & Allopurinol & 88 UC patients & $\begin{array}{l}\text { Oral administration increased remission rates (within } \\
2 \text { weeks). Prophylactic treatment decreased relapse } \\
\text { rates (within } 12 \text { months) }\end{array}$ & 2 \\
\hline & Allopurinol & 22 UC patients & $\begin{array}{l}\text { Oral administration resulted in } 50 \% \text { positive response } \\
\text { rates in acute and chronic pouchitis }\end{array}$ & 3 \\
\hline & Allopurinol & $\begin{array}{l}\text { Acetic acid, rat } \\
\text { Mitomycin C, } \\
\text { rat }\end{array}$ & $\begin{array}{l}\text { Oral administration lowered inflammatory scores. } 50 \% \\
\text { of the animals did not respond }\end{array}$ & 4,5 \\
\hline $\begin{array}{l}\text { Sparing of } \\
\text { glutathione }\end{array}$ & WR-2721 & $\begin{array}{l}\text { Acetic acid, rat } \\
\text { Mitomycin C, } \\
\text { rat }\end{array}$ & $\begin{array}{l}\text { i.p. doses improved histology, associated with less } \\
\text { diarrhoea }\end{array}$ & 5,11 \\
\hline \multirow[t]{2}{*}{$\begin{array}{l}\text { Suppletion of } \\
\text { trace elements }\end{array}$} & Zinc & $\begin{array}{l}7 \mathrm{CD}, 7 \cup \mathrm{UC} \\
\text { patients }\end{array}$ & $\begin{array}{l}\text { Oral administration failed to restore antioxidant } \\
\text { enzyme levels and did not affect disease activity }\end{array}$ & 17 \\
\hline & Zinc (Z-103) & TNBS, rat & $\begin{array}{l}\text { Oral administration reduced inflammatory scores and } \\
\text { normalized lipid peroxidation levels }\end{array}$ & 16 \\
\hline
\end{tabular}

DMSO, dimethylsulphoxide; DSS, dextran sodium sulphate; SOD, superoxide dismutase; TNBS, trinitrobenzenesul phonic acid.

after treatment with allopurinol. ${ }^{4,5}$ Two other xanthine oxidase inhibitors were found to be ineffective, ${ }^{4}$ suggesting that xanthine oxidase is not a major ROM source in colitis. The protective effects of allopurinol were explained by its known intrinsic ability to scavenge $\mathrm{O}_{2}^{-}$.

Indeed, direct $\mathrm{O}_{2}^{-}$scavenging has proved to be beneficial in several studies. Preliminary studies reported amelioration ${ }^{6}$ or even prevention ${ }^{7}$ of colitis induction in rodents upon treatment with free human SOD. In two preliminary, uncontrolled clinical trials, high positive response rates were observed in patients with severe $\mathrm{CD}$ that had been treated with free or liposomalencapsulated bovine copper/zinc SOD. ${ }^{8,9}$ Although these earlier results were encourag- ing, no further SODbased clinical trials in IBD patients have been reported for almost 10 years. Conceivably, this may point to certain limitations of the therapeutical applicability of SOD. There have been attempts to increase the enzyme's potential by coupling SOD to carrier molecules to increase its halflife, without affecting its specific activity. However, SOD coupled to polye thyleneglycol or lecithin did not show convincingly better efficacies in the treatment of chemically induced colitis in animals ${ }^{4,10}$ Another serious impediment of SOD therapy may be its poor tissue penetration. Recent research on SOD therapy, therefore, focuses on SOD mimetics with a high permeability. A number of these agents (see Table 1) have been show $\mathrm{n}$ to be beneficial in animal models of 
colitis, but never resulted in a complete prevention of tissue damage. ${ }^{11-14}$ Their therapeutic potential in patients is still to be established.

Theoretically, antioxidant therapy by SOD may seem conflicting since this enzyme lowers $\mathrm{O}_{2}$ levels by converting $\mathrm{O}_{2}^{-}$to yield the more harmful oxidant $\mathrm{H}_{2} \mathrm{O}_{2}$. Keshavarzian et al. ${ }^{11}$ speculated that the primary anti-inflammatory effect of exogenously administered SOD is not its enzymatic ability to scavenge $\mathrm{O}_{2}^{-}$, but its antigenicity and subsequent cytokine-mediated immunostimulatory effect. Protective mechanisms of exogenous SOD may also include prevention of $\mathrm{OH} \bullet$ formation or prevention of $\mathrm{O}_{2}$-mediated peroxidase inhibition, consequently preventing harmful $\mathrm{H}_{2} \mathrm{O}_{2}$ effects.

These latter suggestions imply causative roles for $\mathrm{H}_{2} \mathrm{O}_{2}$ and/or its derived ROMs. Hence, administering $\mathrm{H}_{2} \mathrm{O}_{2}$ metabolizing enzymes was thought to have protective effects in IBD. In two different animal models, catalase significantly improved the severity of acute inflammation. ${ }^{5,11}$ Glutathione peroxidase is the other important $\mathrm{H}_{2} \mathrm{O}_{2}$ scavenging enzyme. Several synthetic compounds (see Table 1) have been described that improve histology in acetic acid-or mitomycin C-induced colitis by increasing the availibility of glutathione, the crucial cofactor for glutathione peroxidase. ${ }^{5,11,14}$ Furthermore, some of the earlier mentioned SOD mimetics also have $\mathrm{H}_{2} \mathrm{O}_{2}$ scavenging capabilities. ${ }^{11,14}$

Although $\mathrm{H}_{2} \mathrm{O}_{2}$ can exist in tissues for a long time and diffuses into all cellular compartments, the deleterious effects of $\mathrm{H}_{2} \mathrm{O}_{2}$ are thought to be due to its secondarily derived $\mathrm{ROMs} \mathrm{OH} \bullet$ and $\mathrm{HOCl}$. In UC patients, addition of the potent $\mathrm{OH} \bullet$ scavenger dimethylsulphoxide (DMSO) to a sulphasalazine/ prednisolone regimen enhanced treatment efficacy. ${ }^{2}$ In chemically induced colitis, the evidence does not favour a role for $\mathrm{OH} \bullet$ so far. Both DMSO and deferoxamine, an iron chelating agent and $\mathrm{OH} \bullet$ production inhibitor, did not influence inflammation. ${ }^{4}$ These findings are in agreement with the view that $\mathrm{HOC}$ rather than $\mathrm{OH}^{\bullet}$ is involved in $\mathrm{ROM}$ mediated tissue damage, particularly in UC. Interestingly, $\mathrm{HOC}$ is able to maintain its levels by inhibition of glutathione peroxidase and catalase. There have been no reports to date on the therapeutical use of specific HOd scavengers, like ascorbate.

\section{Diet}

Malnutrition is common in IBD, and dietary intervention is often a part of IBD therapy (see Burke $e t$ al. $)^{15}$ Yet, a role of specific nutrients in manipulating antioxidant status still has to be defined. Dietary components such as $\alpha$-tocopherol (vitamin E), ascorbate (vitamin C), carotenoids (vitamin A), or glucose have in vitro ROM scavenging capabilities, but reports concerning the beneficial antioxidant actions of these compounds in IBD are very limited.

It has been proposed that some of the SOD mimetics work as carriers of copper. ${ }^{11}$ necessary for the synthesis of copper-dependent antioxidants, e.g. SOD. Zinc is an other essential trace metal with antioxidant properties, which is a component of antioxidant metalloproteins such as SOD. Zinc deficiencies have been reported in $\mathrm{CD}$, and although supplementation of zinc reduced colitis in rats, ${ }^{16}$ it was found to be ineffective in IBD patients. ${ }^{17}$

\section{Mucosa Protectives}

The intestinal inflammatory process in IBD not only affects the cells within the lamina propria, but has also a major impact on the function of the epithelial cells of the mucosa. Some therapeutic strategies particularly aim at restoring the epithelial integrity and function, while others are installed to attenuate the mucosal inflammation. In the end, most of the substances appear to do both.

\section{Sucralphate}

This non-absorbable aluminium salt of sucrose octasulphate has the capability to selectively bind to damaged and ulcerated tissue, thereby providing protection against noxious agents. Sucralphate is particularly known from the treatment of upper gastrointestinal inflammation and ulceration, but in several clinical trials attempts were made to assess its efficacy in distal colitis and proctitis (reviewed in Polson and Misiewicz ${ }^{18}$ ). Topical application of sucralphate enemas to patients with active distal UC was reported to be of variable success. Apparently some benefit may be achieved, i.e. resolution of rectal bleeding and improvement of histological appearance. In general, however, sucralphate seems to be less effective than prednisolone and of limited use in the treatment of distal colitis.

\section{Short chain fatty acids}

Access to colonocyte fuels is essential for the epithelial healing process. Short chain fatty acids, such as propionate, acetate, and butyrate, which are produced by bacterial fermentation of complex carbohydrates or oligosaccharide fibres, are preferred nutrients for colonocytes. ${ }^{15}$ In UC patients, utilization of particularly butyrate seems to be impaired, presumably not due to deficiencies in the $\beta$-oxidation pathway in the intestinal mucosa, but as a result of a high luminal content of sulphate-reducing bacteria, which produce sulphide that interferes in the butyrate-oxidation (see Fig. 1).

Application of butyrate has been successfull in the treatment of colorectal neoplasia, because of its 
ability to reduce hyperproliferation of epithelial cells and to induce their differentiation (see Fig. 1). Likewise, treatment of active UC with butyrate enemas has been reported with considerable success regarding endoscopic and histologic improvement, without major side effects, ${ }^{19}$ although negative results have been reported as well. Many of the studies, however, were preliminary or uncontrolled trials and larger decisive studies are needed. A number of biochemical studies do provide circumstantial evidence, however, that butyrate-related treatment could be of benefit to patients with distal colitis. For instance, it has been found to reduce apoptosis of colonocytes, as well as pro-inflammatory cytokine (IL8) production by epithelial cells and mucosal inflammation, and to increase colonic mucin production, and adhesion molecule (ICAMH) and HLA class I expression. These phenomena do indicate that butyrate is able to modulate the intestinal inflammatory process. Perhaps (a combination of) a oligosaccharide fibres-rich diet, topical installation of butyrate, and inhibition of bacterial sulphidogenesis might prove to be of clinical benefit in UC, as has to be shown in better controlled clinical studies.

\section{Long chain ( $n-3)$ fatty acids}

Arachidonic acid metabolites, like prostaglandin $\mathrm{PGE}_{2}$ and thromboxane $\mathrm{TXA}_{2}$ generated by the cyclooxygenase pathway and leukotriene $\mathrm{LTB}_{4}$ produced by 5 -ipoxygenase, are known to contribute to the inflammatory process in IBD. Specific inhibitors of both oxygenases have been found to either aggravate the inflammation in animal models and patients, or to be clinically ineffective. More encouraging results have been obtained by the oral administration of fish oil and evening primrose oil, which replace the long chain $n-6$ eicosanoid (arachidonic) fatty acids by $n-3$ eicosapentaenoic/docosahexaenic acids and $\gamma$-linoleic acid, respectively. These substances compete with the same oxygenases and finally yield in the production of less potent inflammatory mediators as $\mathrm{LTB}_{5}$, which is less chemotactic and activating for neutrophils than $\mathrm{LTB}_{4}$, and $\mathrm{PGE}_{1}$ which inhibits arachidonic acid release (see Fig. 1). Besides the numerous biochemical studies which indicate a reduction in the intestinal inflammatory process, the majority of clinical intervention studies revealed a moderate to good response, with endoscopic and histologic improvement and a steroid-sparing effect in UC. ${ }^{15}$

The major problem with the substances, however, are the unpleasant taste and the almost unacceptable side-effects as flatulence, diarrhoea, heartburn, etc. Most recently, new enteric-coated preparations have been developed which reduce both the therapeutic dose and the side-effects. This new fish oil preparation was found to significantly reduce the relapse rate of patients with Crohn's disease in remission, as determined in a 1-year controlled study. ${ }^{20}$ Although similar studies were found to be less impressive and there was some debate on the fish oil composition and patient inclusion criteria, these results are very promising and need to be expanded by further studies.

Although many aspects of the biochemical mechanisms which are elicited by long chain n-3 fatty acids have been elucidated, the exact anti-inflammatory working profile is still unravelled. Apparently, not only a shift takes place towards less harmful prostaglandins and leukotrienes, but there is also compelling evidence that dietary fish oil supplementation is able to directly or indirectly downregulate pro-inflammatory cytokines, like TNF, IL-1 and IL-6 ${ }^{21}$ (see Fig. 1). Furthermore, there are some indications that these dietary lipids are able to improve the antioxidant status of tissues. ${ }^{22}$ In that context, one interesting aspect might need some further attention. Many of the long chain $n-3$ fatty acid preparations contain antioxidants, like vitamin $\mathrm{E}$, to prevent lipid peroxidation of the oils. The contribution of these antioxidants to the attenuation of the inflammatory response might be worthwhile pursuing.

Finally, a recent study with a bacterial cell wall induced colitis in rats showed that a complete enteral diet containing the combination of fish oil and diverse oligosaccharides was as effective as sulphasalazine in improving the chronic intestinal inflammation. ${ }^{23}$

\section{Conclusion and Perspectives}

Although there has been considerable progress in the understanding of metabolic and oxidative processes and how they relate to tissue damage in IBD, their translation into clinical practice has yet to be made. The initial enthusiasm for innovative mucosa protectives and antioxidant agents in IBD therapy has been somewhat tempered, because of the lack of efficacy or of large confirmative controlled clinical trials. At present we may conclude that their position in the therapeutic armament for IBD will be, at their best, in the form of adjunctive (dietary) therapy.

\section{References}

1. Yamada T, Grisham MB. Pathogenesis of tissue injury: role of reactive metabolites of oxygen and nitrogen. In: Targan SR, Shanahan F, eds. Inflammatory Bowel Disease: From Bench to Bedside. Baltimore: Williams \&Wilkins, 1994; 133-150.

2. Salim AS. Role of oxygen-derived free radical scavengers in the management of recurrent attacks of ulcerative colitis: a new approach. $J$ Lab Clin Med 1992; 119: 710-717.

3. Levin KE, Pemberton JH, Phillips SF, Zinsmeister AR, Pezim ME Role of oxygen free radicals in the etiology of pouchitis. Dis Colon Rectum 1992; 35: 452-456.

4. Keshavarzian A, Morgan G, Sedghi S, Gordon JH, Doria M. Role of reactive oxygen metabolites in experimental colitis. Gut 1990; 31: 786-790.

5. Keshavarzian A, Doria MI, Sedghi S, et al. Mitomycin Cinduced colitis in rats: a new animal model of acute colonic inflammation implicating reactive oxygen species. J Lab Clin Med 1992; 120: 778-791. 
6. Fretland DJ, Widomski DL, Anglin CP, et al. Superoxide dismutase (SOD) modulates acetic acid-induced colitis in rodents. Gastroenterology 1991; 100: A581.

7. Burakoff R, Zhao L, Joseph I, Koo H, Rosenfeld W. SOD prevents colitis and attenuates eicosanoid release and motility changes in a trinitrobcnzensulfonic acid rabbit colitis model. Gastroenterology 1991; 100: A565.

8. Emerit J, Pelletier S, Tosoni-Verlignue D, Mollet M. Phase II trial of copper zinc superoxide dismutase (CuZnSOD) in treatment of Crohn's disease. Free Radical Biol Med 1989; 7: 145-149.

9. Niwa Y, Somiya K, Michelson AM, Puget K. Effect of liposomalencapsulated superoxide dismutase on active oxygen-related human disorders. A preliminary study. Free Radical Res Comm 1985; 1: 137-153.

10. Hori Y, Hoshino J, Yamazaki C, et al. Effect of lecithinized-superoxide dismutase on the rat colitis model induced by dextran sodium sulphate. Jpn J Pharmacol 1997; 74: 99-103.

11. Keshavarzian A, Haydek J, Zabihi R, Doria M, D'astice M, Sorenson JRJ. Agents capable of eliminating reactive oxygen species. Catalase, WR2721, or $\mathrm{Cu}(\mathrm{II})_{2}(3,5-\mathrm{DIPS})_{4}$ decrease experimental colitis. Dig Dis Sci 1992; 37: 1866-1873.

12. Karmeli F, Eliakim R, Okon E, Samuni A, Rachmilewitz D. A stable nitroxide radical effectively decreases mucosal damage in experimental colitis. Gut 1995; 37: 386-393.

13. Yue G, Sun FF, Dunn C, Yin K, Wong PY-K. The 21-aminosteroid tirilazad mesylate can ameliorate inflammatory bowel disease in rats. J Pharmacol Exp Ther 1996; 276: 265-270.

14. Zea-Iriarte W-L, Makiyama K, Goto S, et al. Impairment of antioxidants in colonic epithelial cells isolated from trinitrobenzene sulphonic acidinduced colitis rats. Scand J Gastroenterol 1996; 31: 985-992.
15. Burke A, Lichtenstein GR, Rombeau JL. Nutrition and ulcerative colitis. Baillière Cin Gastroenterol 1997; 11: 153-174.

16. Yoshikawa T, Yamaguchi T, Yoshida N, et al. Effect of Z-103 on TNBinduced colitis in rats. Digestion 1997; 58: 464-468.

17. Mulder TPJ, Van der Sluys Veer A, Verspaget HW, et al. Effect of oral zinc supplementation on metallothionein and superoxide dismutase concentrations in patients with inflammatory bowel disease. J Gastroenterol Hepatol 1994; 9: 472-477.

18. Polson RJ, Misiewicz JJ. Medical management of severe inflammatory disease of the rectum and distal colon: non-nutritional aspects. Baillière Clin Gastroenterol 1992; 6: 1-26.

19. Kim YI. Short-chain fatty acids in ulcerative colitis. Nutr Rev 1998; 56: $17-24$.

20. Beluzzi A, Brignola C, Campieri M, Pera A, Boschi S, Miglioli M Effect of an enteric-coated fish-oil preparation on relapses in Crohn's disease. $N$ Engl J Med 1996; 334: 1557-1560.

21. Blok WL, Katan MB, Van der Meer JWM. Modulation of inflammation and cytokine production by dietary (n-3) fatty acids. J Nutr 1996; 126: 1515-1533.

22. Venkatraman JT, Pinnavaia L. Effects of saturated, omega-6 and omega-3 lipids on activities of enzymes involved in antioxidant defense in normal rats. Nutr Res 1998; 18: 341-350.

23. Grisham MB, DeMichele SJ, Garleb KA, Specian RD. Sulfasalazine or enteral diets containing fish oil or oligosaccharides attenuate chronic colitis in rats. Inflamm Bowel Dis 1996; 2: 178-188.

\section{Received 27 March 1998;}

accepted 30 March 1998 


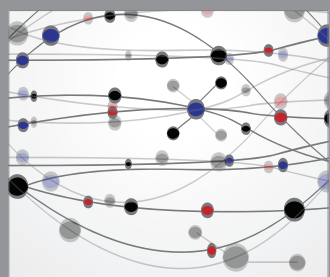

The Scientific World Journal
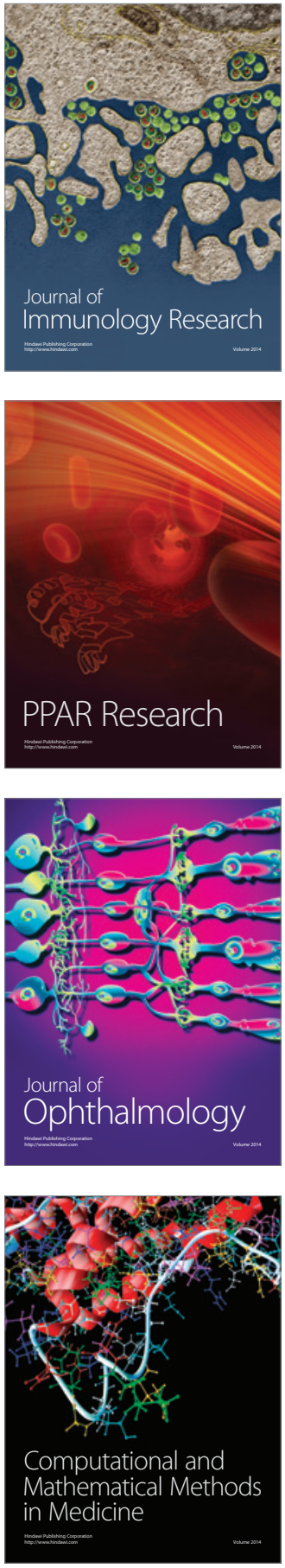

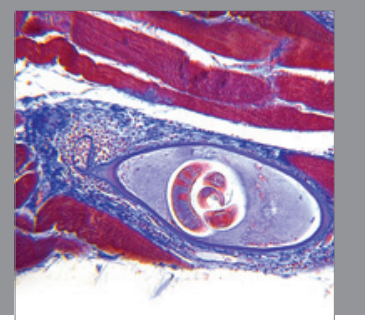

Gastroenterology

Research and Practice
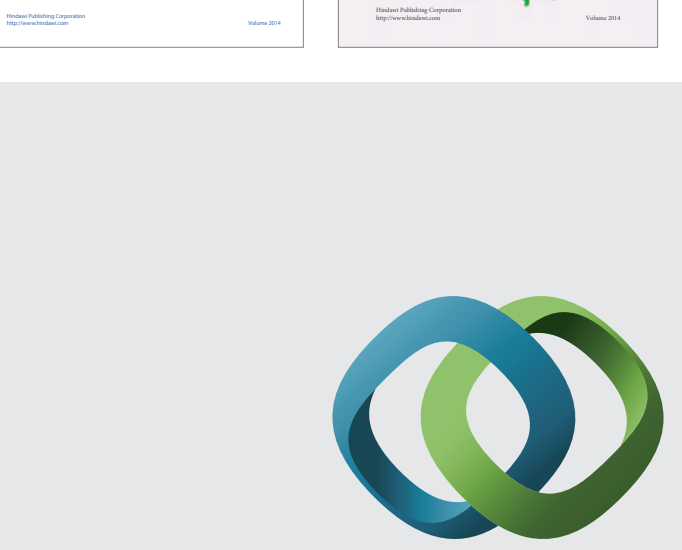

\section{Hindawi}

Submit your manuscripts at

http://www.hindawi.com
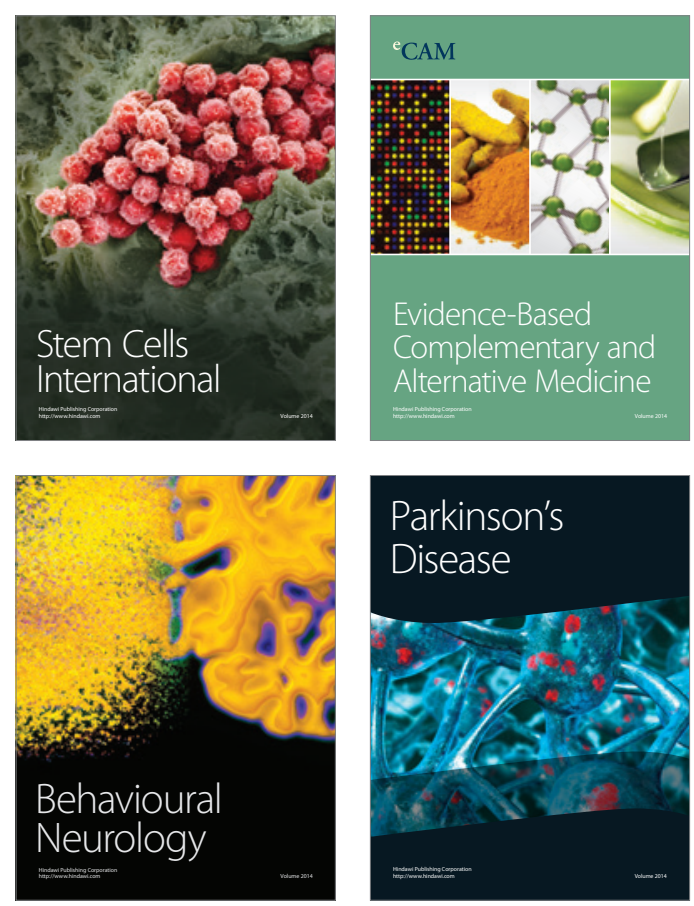

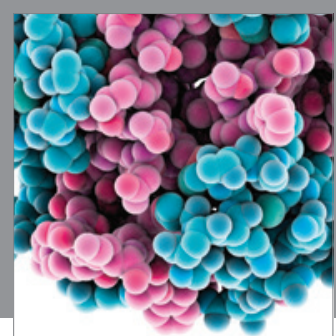

Journal of
Diabetes Research

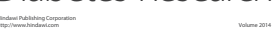

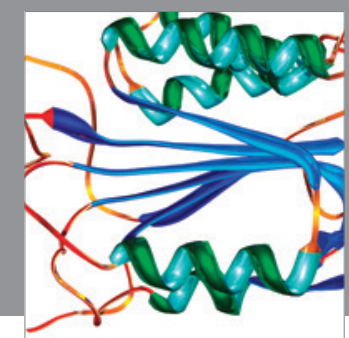

Disease Markers
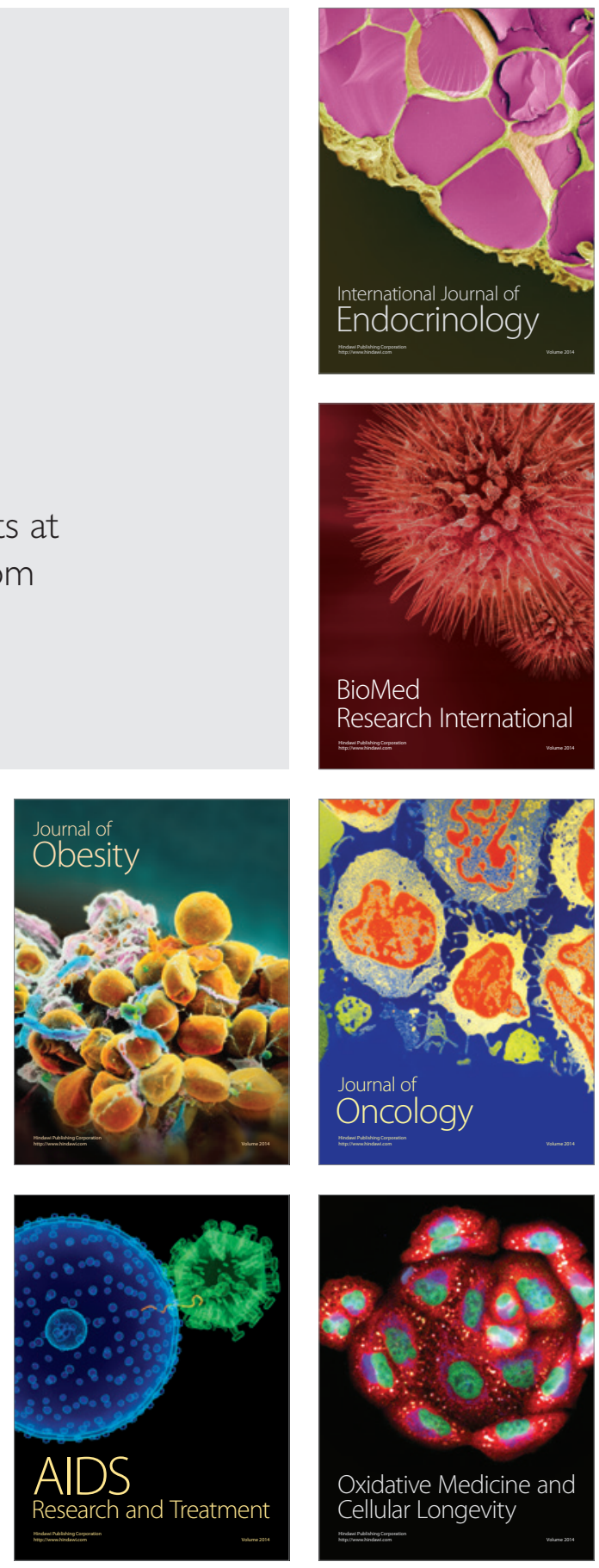